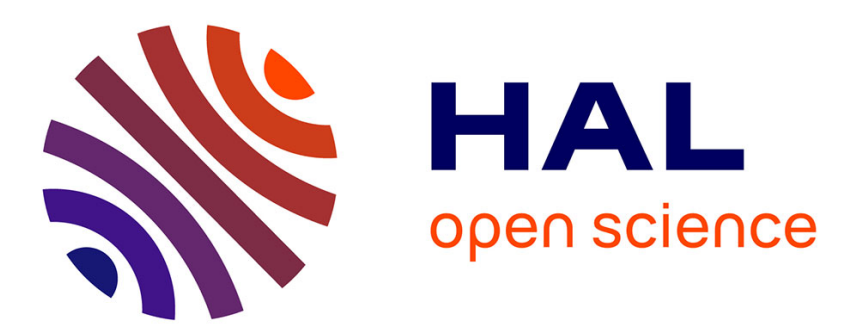

\title{
Arabic Texts Categorization: Features Selection Based on the Extraction of Words' Roots
}

\author{
Said Gadri, Abdelouahab Moussaoui
}

\section{To cite this version:}

Said Gadri, Abdelouahab Moussaoui. Arabic Texts Categorization: Features Selection Based on the Extraction of Words' Roots. 5th International Conference on Computer Science and Its Applications (CIIA), May 2015, Saida, Algeria. pp.167-180, 10.1007/978-3-319-19578-0_14 . hal-01789980

\section{HAL Id: hal-01789980 \\ https://hal.inria.fr/hal-01789980}

Submitted on 11 May 2018

HAL is a multi-disciplinary open access archive for the deposit and dissemination of scientific research documents, whether they are published or not. The documents may come from teaching and research institutions in France or abroad, or from public or private research centers.
L'archive ouverte pluridisciplinaire HAL, est destinée au dépôt et à la diffusion de documents scientifiques de niveau recherche, publiés ou non, émanant des établissements d'enseignement et de recherche français ou étrangers, des laboratoires publics ou privés. 


\title{
Arabic Texts Categorization: Features Selection Based on the Extraction of Words' Roots
}

\author{
Said Gadri ${ }^{1, *}$, Abdelouahab Moussaoui ${ }^{2}$ \\ ${ }^{1}$ Department of ICST, University of M'sila, 28000, Algeria \\ kadri.said28@yahoo.fr \\ ${ }^{2}$ Department of Computer Sciences, University Farhat Abbes of Setif, Setif, 19000, Algeria \\ moussaoui.abdelegmail.com
}

\begin{abstract}
One of methods used to reduce the size of terms vocabulary in Arabic text categorization is to replace the different variants (forms) of words by their common root. The search of root in Arabic or Arabic word root extraction is more difficult than other languages since Arabic language has a very different and difficult structure, that is because it is a very rich language with complex morphology. Many algorithms are proposed in this field. Some of them are based on morphological rules and grammatical patterns, thus they are quite difficult and require deep linguistic knowledge. Others are statistical, so they are less difficult and based only on some calculations. In this paper we propose a new statistical algorithm which permits to extract roots of Arabic words using the technique of ngrams of characters without using any morphological rule or grammatical patterns.
\end{abstract}

Keywords: root extraction, information retrieval, bigrams technique, Arabic morphological rules, feature selection.

\section{Introduction}

Arabic is one of the oldest and the most used language in the world, it is spoken by over 300 million people in Arabic world, and used by more than 1.7 billion Muslims over the world because it is the language of the Holy Quran, here we can distinguish two types of Arabic; a more classical language, as found in the Holy Quran or poetry, a standardized modern language, and regional dialects [1]. We note also that Arabic language is a semitic language $[2,3]$ based on 28 cursives letters written from right to left .

The word in Arabic is formed of the root part and some affixes (antefixes, prefixes, infixes, suffixes) that form the word (سألتونيها Saaltmwnyha). The Arabic root extraction is a very difficult task which is not the case for other languages as English or French, because Arabic is a very rich language with a very difficult structure and complex morphology. Arabian linguists show that all nouns and verbs of Arabic language are derived from a set of roots containing about 11347 roots; more than $75 \%$ of them are trilateral roots [4].

There are many applications based on the roots of words in Arabic processing such as: text's classification, text summarizing, information retrieval, data and text mining. $[5,6]$. 


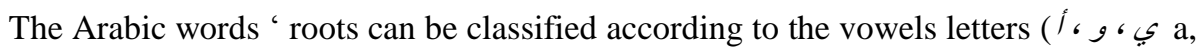

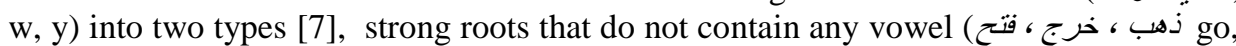
come out, open), vocalic roots that contain at least one vowel (أوى ، و وعرج) shelter, promise). Arabic roots can be further classified according to the number of their characters into four types: Trilateral roots which form most words in Arabic language

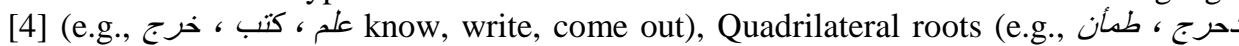

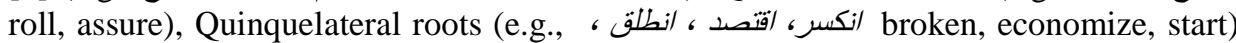

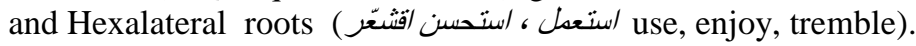

There are two classes of methods used to extract the roots of Arabic words, the first class is based on morphological rules, so its methods simulate the same process of an expert linguist during his analysis of a given Arabic word [1], [8,9,10,11], which make the process of extracting root difficult and complex because of the diversity of morphological formulas and the multiplicity of words forms for the same root when changing the original characters position in the word (e.g., علم ، عالم ، علوم ، عوالم ، معالم know, scientist, sciences, worlds, landmarks) [12,13]. The second class is formed of statistical methods which are simple, fast, and do not require any morphological rules but some calculations $[14,15,16,17,18,19,20]$.

In this paper, we propose a new statistical method which permits to extract roots of Arabic words using the approach of n-grams of characters without using any morphological rule. The paper is organized as follows: the first section is a general introduction to the field of study. The second section presents some related works, so we review some papers that treat the problem of extraction of Arabic word's roots. In the third section we introduce our new algorithm. The fourth section presents the experiments that we have done to test our new method and also presents the obtained results. In the last section we conclude our work by summarizing our realized work and giving some ideas to improve it in the future.

\section{Related Works}

Many researchers proposed some algorithms to extract Arabic words roots, some of these algorithms are based on morphological rules. Thus, they are called morphological methods. Others do not use any morphological rule but some statistical calculations, so they are called statistical algorithms.

In the first class of algorithms, we can note the following: [9], [21] Khoja's roots extractor removes the longest suffix and prefix. It then matches the remaining word with verbal and noun patterns, to extract the root. The roots extractor makes use of several linguistic data files such as a list of all diacritics, punctuation characters, definite articles, and stop words [22,23,24,25]. [13] Propose a linguistic approach for root extraction as a preprocessing step for Arabic text mining. The proposed approach is composed of a rule-based light stemmer and a pattern-based infix remover. They propose an algorithm to handle weak, eliminated-long vowel, hamzated and geminated words. The accuracy of the extracted roots is determined by comparing them with a predefined list of 5,405 trilateral and quadrilateral roots. The linguistic approach performance was tested on texts' collection consists of eight categories, the author achieved a success ratio about 73.74\%. [26] Presents a new Arabic root extractor that tries to assign a unique root for each Arabic word without having an Arabic roots list, a 
word patterns list, or the list of Arabic prefixes and suffixes. The algorithm predict the letters positions that may form the word root one by one, using rules based on the relations between the Arabic word letters and their placement in the word. This algorithm consists of two parts, the first part gives the rules that distinguish between the Arabic definite letter " $\lrcorner$ ' AL, La" and the original word letters " $\lrcorner$ ". The second part segments each word into three parts and classifies its letters according to their positions. The author tested her proposed algorithm using the Holy Quran words and obtained an accuracy of $93.7 \%$ in root extracting process.

In the second class of algorithms we can note the following: [14] Developed a root extraction algorithm which does not use any dictionary, their algorithm categorizes all Arabic letters according to six integer weights, ranging from 0 to 5, as well as the rank of the letter which is determined by the position this letter holds in a word. The weight and rank are multiplied together, and the three letters with the smallest product constitute the root of the word. We note that [14] did not explain on what basis did it use such ranking or weighting. [10] Proposes an algorithm to extract tri-literal Arabic roots, this algorithm consists of two steps; in the first step they eliminate stop words as well prefixes and suffixes. In the next step, they remove the repeated word's letters until only three letters are remained, and then they arrange these remaining letters according to their order in the original word, which form the root of the original word. The obtained results were very promising and give an accuracy of root's extraction over than $73 \%$. [27] Propose a new way to extract the roots of Arabic words using n-grams technique. They used two similarity measures; the "Manhattan distance measurement" and the "Dice's measurement". They tested their algorithm on the Holy Quran and on a corpus of 242 abstracts from the Proceedings of the Saudi Arabian National Computer Conferences. They concluded from their study that combining the n-grams with the Dice's measurement gives better results than using the Manhattan distance measurement. [28] propose a new algorithm to find a system that assigns, for every non vowel word a unique root. The proposed system consists of two modules; the first one consists of analyzing the context by segmenting the words of the sentence into its elementary morphological units in order to extract its possible roots. So, each word is segmented into three parts (prefix, stem and suffix). In the second module, they based on the context to extract the correct root among all possible roots of the word. They validate their algorithm using NEMLAR Arabic writing corpus that consists of 500,000 words, and their proposed algorithm gives the correct root in more than $98 \%$ of the training set and $94 \%$ of the testing set. [29] Propose a new algorithm which use the ngrams technique. In this technique, both the word and its assumed root are divided into pairs called bi-grams, then the similarity between the word and the root is calculated using equation (1) [30]. This process is repeated for each root in the roots list:

$$
\mathrm{S}=2 \times \mathrm{C} /(\mathrm{A}+\mathrm{B})
$$

Where:

$A=$ Number of unique bi-grams in the word (A)

$\mathrm{B}=$ Number of unique bi-grams in the root $(\mathrm{B})$

$\mathrm{C}=$ Number of similar unique pairs between the word $(\mathrm{A})$ and the root $(\mathrm{B})$

To use equation (1) for extracting the word's root, we must have: the word (A) and the potential roots (B) to compare with, then the similarity measuring is conducted by computing the value of $(\mathrm{S})$ between the word (A) and each potential roots (B). 


\section{The Proposed Algorithm}

In our new algorithm, we use also the n-grams technique to extract Arabic words roots, for this purpose, we proceed according to the following steps:

Step 1: we segment the word for which we want to find the root, and all the roots of the list into bigrams (2-grams).

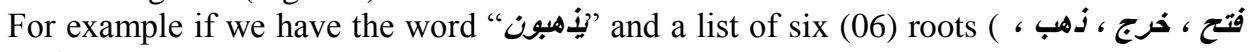
(وجد ، وهب ، نهب (2) we proceed the segmentation step as follows:

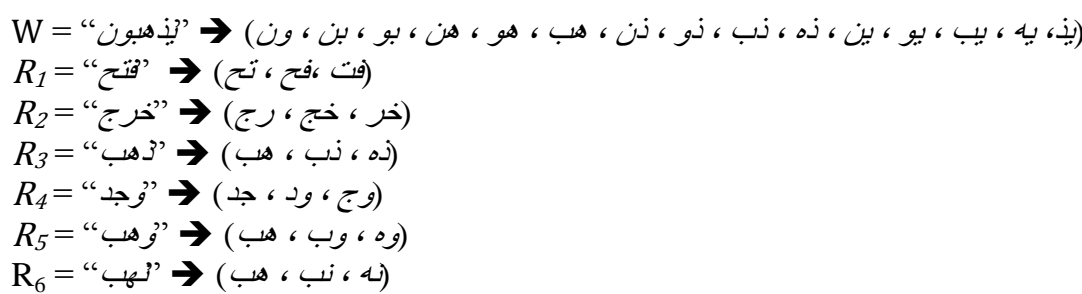

Step 2: we calculate the following parameters:

$N_{W}$ : The number of unique bigrams in the word $w$

$N_{R_{i}}$ : The number of unique bigrams in the root $R i$

$N_{W R_{i}}$ : The number of common unique bigrams between the word $W$ and the root $R i$

$N_{W \bar{R}_{i}}$ : The number of bigrams belonging to the word $\mathrm{w}$ and do not belong to the root $R i$

$$
\left(N_{W \bar{R}_{i}}=N_{W}-N_{W R_{i}}\right)
$$

$N_{R_{i} \bar{W}}$ : The number of bigrams belonging to the root $R i$ and do not belong to the word $w$

$$
\left(N_{R_{i} \bar{W}}=N_{R_{i}}-N_{W R_{i}}\right)
$$

For the previous example we have:

$N_{W}=18, N_{R_{1}}=3, N_{R_{2}}=3, N_{R_{3}}=3, N_{R_{4}}=3, N_{R_{5}}=3, N_{R_{6}}=3, N_{W R_{1}}=0, N_{W R_{2}}=0, N_{W R_{3}}=3$, $N_{W R_{4}}=0, \quad N_{W R_{5}}=1, \quad N_{W R_{6}}=1, \quad N_{W \bar{R}_{1}}=18, \quad N_{W \bar{R}_{2}}=18, N_{W \bar{R}_{3}}=15, \quad N_{W \bar{R}_{4}}=18$, $N_{W \bar{R}_{5}}=17, N_{W \bar{R}_{6}}=17, N_{R_{1} \bar{W}}=3, N_{R_{2} \bar{W}}=3, N_{R_{3} \bar{W}}=0, N_{R_{4} \bar{W}}=3, N_{R_{5} \bar{W}}=$ $2, N_{R_{6} \bar{W}}=2$.

Step3: we take only the roots having at least one common bigram with the word $w$ $\left(N_{W R_{i}} \geq 1\right)$ as candidate roots among the list of all roots in order to reduce the calculation time.

In our previous example, we can take only the roots: $R_{3}=$ "هُ" with $N_{W R_{i}}=3,1,1$ respectively.

Step4: we calculate the distance $D\left(w, R_{i}\right)$ between the word $W$ and each candidate root $R_{i}\left(R_{3}, R_{5}, R_{6}\right)$ according to the following equation :

$$
D\left(w, R_{i}\right)=2 * N_{w R_{i}}+k * N_{w \bar{R}_{i}}+k * N_{R_{i} \bar{w}}
$$

Where: $k$ is a constant which must take a high value (we put here $k=100$ )

For the previous example we obtain:

$\mathrm{D}\left(\mathrm{w}, \mathrm{R}_{3}\right)=2 * 3+15 * 100+0 * 100=1506$

$\mathrm{D}\left(\mathrm{w}, \mathrm{R}_{5}\right)=2 * 1+17 * 100+2 * 100=1902$

$\mathrm{D}\left(\mathrm{w}, \mathrm{R}_{6}\right)=2 * 1+17 * 100+2 * 100=1902$ 
Step5: in the last step, we assign the root that has the lowest value of distance $D\left(w, R_{i}\right)$ among the candidate roots to the word $W$. it is the required root.

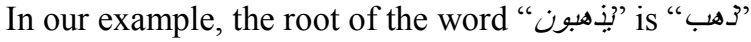

Finally, we note that our new algorithm has the following advantages:

1.Does not require the removal of affixes whose distinction from the native letters of the word is quite difficult.

2.Works for any word whatever the length of the root.

3.Valid for strong roots and vocalic roots which generally pose problems in

Arabic during their derivation, because of the complete change of their forms.

4.Does not use any morphological rule nor patterns but simple calculations of distances.

5.Very practical algorithm and easy to implement on machine.

\section{Experimentations and Obtained Results}

To validate our proposed algorithm, we used three corpus which can be classified according their sizes into: small corpus, middle corpus, and large corpus.

Each one is constituted of many files as indicated below:

1. The file of derived forms (gross words) which contains morphological forms of words derived from many Arabic roots.

2. The file of roots which contains many Arabic roots, we note that these roots are trilateral, quadrilateral, quinquelateral, and hexalateral. We note also that many of them are vocalic roots which contain at least one vowel.

3. The file of golden roots which contain the correct roots of all words present in our corpus (the file in (1)), this golden list was prepared by an expert linguist and used as reference list, i.e., by comparison between the list of obtained roots (extracted by the system) and the reference list (established by the expert), we can calculate the roots extraction accuracy (success ratio).

Table 1. Corpus used in experiments.

\begin{tabular}{llll}
\hline Corpus & $\begin{array}{l}\text { Size of derived } \\
\text { words' file }\end{array}$ & Size of the roots' file & $\begin{array}{l}\text { Size of the golden } \\
\text { roots' file }\end{array}$ \\
\hline Small corpus & 50 & 25 & 50 \\
Middle corpus & 270 & 135 & 270 \\
Large corpus & 1500 & 450 & 1500 \\
\hline
\end{tabular}

Table 2. An example of morphological forms (gross words).

\begin{tabular}{|c|c|c|c|c|}
\hline Word & Word & Word & Word & Word \\
\hline مأخذ & أو/مر & باحث & /جتماعات & مأخذ \\
\hline مؤ/خذة & مؤتـر & بحوث & اجتماعيات & مؤ/خذة \\
\hline مؤ/خذون & مؤ/مرة & أبحاث & جموع & مؤ/خذون \\
\hline موُ/خذات & متأمرون & باحثون & جو/مع & مؤ/خذات \\
\hline مؤزرة & يأندرون & باحثات & بجدعون & مؤزرةة \\
\hline مأكل & يأتهرن & ابتهال & بجدعن & مأكل \\
\hline أكلات & أمرهم & مبتهل & /جتهاد & أكلات \\
\hline
\end{tabular}


Table 3. An example of trilateral, quadrilateral, quinquelateral, hexalateral roots.

\begin{tabular}{|c|c|c|c|}
\hline Trilateral roots & Quadrilateral roots & $\begin{array}{l}\text { Quinquelateral } \\
\text { roots }\end{array}$ & Hexalateral roots \\
\hline زرع & أكرم & انطلق انق & استعطل \\
\hline صنع & أعان & انكسر & استحسن \\
\hline تجر & أعطىى & احتوى & استعان \\
\hline جمع & حطَّم & اقتصد & ا خشوشن \\
\hline نفر & رَبَّى & اخضرّ & ادهاّم \\
\hline 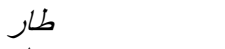 & حاسب & تحدّى & /حرنجم \\
\hline سعل & طمأن & تنازل & اقثبعز ' \\
\hline صدع & زلزل & تلدحرج & اطمأنّ \\
\hline
\end{tabular}

Table 4. Examples of obtained results when segmenting words into bi-grams.

\begin{tabular}{|c|c|c|}
\hline \multirow[t]{2}{*}{ Word } & N-grams & Nb.Ng \\
\hline & Ng.Frequencies & $\left(N_{W}\right)$ \\
\hline بتيعلون & 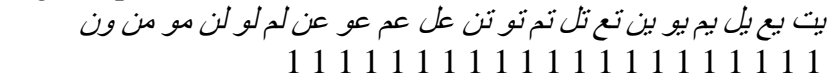 & 28 \\
\hline 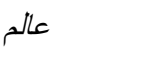 & عا عل عم ال املم $\begin{array}{rl}1 & 1111\end{array}$ & 6 \\
\hline كاتب & كا كت كب /ت /ب تب 111111 & 6 \\
\hline كتاتيب & 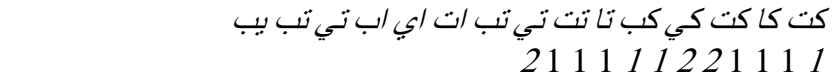 & 12 \\
\hline |قتصداد & 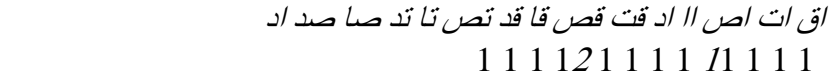 & 14 \\
\hline بقصدون & 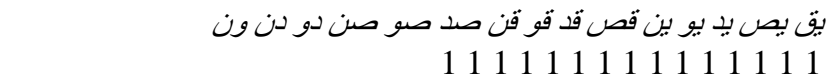 & 15 \\
\hline استخدم & 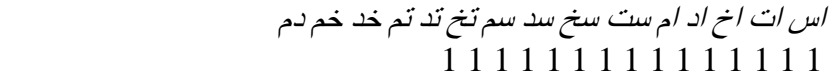 & 15 \\
\hline سنستدرجهم & 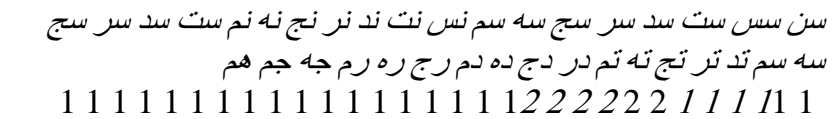 & 30 \\
\hline متنبذب & مت مذ مب مذ مب تذ تب تذ تب نب زذ نب بذ بب نب 1222311 & 9 \\
\hline متلألئ & 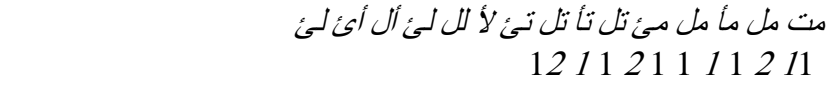 & 12 \\
\hline بهزمونهم & ون بوه ويم يو بن نم هيه يم هز هم هو هن هله هم زم زو زن زه زم مو من مه مم & 23 \\
\hline المتربّبي & 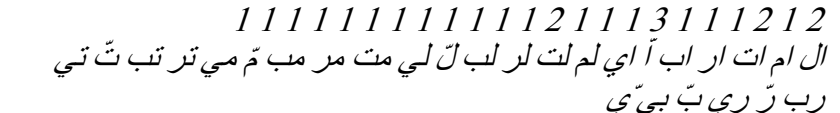 & 28 \\
\hline المرّبون & 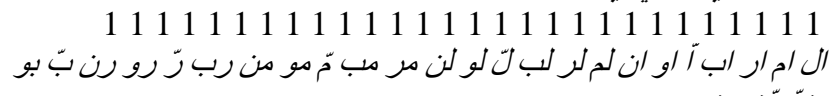 & 28 \\
\hline طائرات & 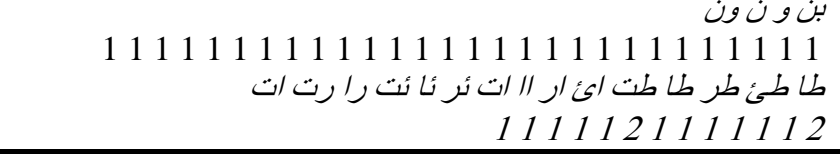 & 13 \\
\hline
\end{tabular}


Table 4. Examples of obtained results when segmenting roots into bi-grams.

\begin{tabular}{|c|c|c|c|}
\hline \multirow[t]{2}{*}{ Root } & $\mathrm{N}$-grams & & Nb.Ng \\
\hline & Ng.Frequencies & & $\left(N_{R_{i}}\right)$ \\
\hline كَلْم & & كل لَّ كمّ لَّلمّم & 6 \\
\hline عالج & & عا عل عج ال اج لج 111111 & 6 \\
\hline قصد & & قص قد صد 111 & 3 \\
\hline |قتصد & & 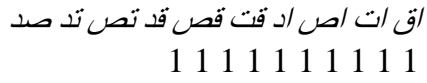 & 10 \\
\hline كتب & & كت كب تب 111 & 3 \\
\hline علم & & عل عملم & 3 \\
\hline عمل & & عم عل مل 1111 & 3 \\
\hline خدم & & خد خم دم & 3 \\
\hline كمل & & كم كل مل 11 كل 11 & 3 \\
\hline كمن & & كم كن سن 111 & 3 \\
\hline 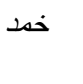 & & خم خد مد & 3 \\
\hline درج & & دردج درج 111 & 3 \\
\hline زبنب & & نب زذ نب بذ بب ذب 1113 & 4 \\
\hline$\gamma \gamma$ & & $\begin{array}{r}\text { لע لy أل أل } 1113 \\
1113\end{array}$ & 4 \\
\hline هزم & & هز همزم 111 & 3 \\
\hline طار & & طاطر /ر 111 & 3 \\
\hline ريّبى & & 11 رب رَّي بَّ بيّي 1111 & 6 \\
\hline عقد & & عق عد قد 111 & 3 \\
\hline تأتأ & & $\begin{aligned} \text { تأ تت تأ أت أ تأ } \\
1113\end{aligned}$ & 4 \\
\hline
\end{tabular}


Table 5. Extraction of some Arabic words roots using our new algorithm.

\begin{tabular}{|c|c|c|c|c|c|}
\hline Word & Nearest roots & $\begin{array}{l}\text { Nb.Common } \\
\text { bi-grams }\end{array}$ & Distance values & $\begin{array}{l}\text { Extracted } \\
\text { root }\end{array}$ & $\begin{array}{l}\text { Correct } \\
\text { root }\end{array}$ \\
\hline بتعلدون & "كلم، عالج ، علم، كمن & $3 \cdot 1 \cdot 3 \cdot 2 \cdot 1$ & · $\underline{\mathbf{2 5 0 6}} \cdot 3202$ ، 2806 & ل علم & علم \\
\hline 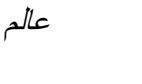 & كَّمْ ، عالج ، علم ، & $1 \cdot 3 \cdot 3 \cdot 2$ & ‘ $\underline{\mathbf{3 0 6}}$ ، 606 ، 1002 & 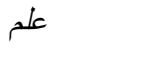 & 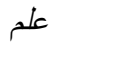 \\
\hline كاتب & اقتصد ، كتب & $1 \cdot 3$ & $\underline{\mathbf{3 0 6}}$ • 1402 & كتب & كتب \\
\hline كتاتيب & اقتصد ، كتب ، تأتأ & $1 \cdot 3 \cdot 1$ & 1402 ، $\overline{\mathbf{9 0 6}}$ ، 2002 & كتب & كتب \\
\hline | اقتصاد & قصد ، اقتصد ، عقل & $3 \cdot 10 \cdot 1$ & 1502 ، $\underline{\mathbf{4 2 0}} \cdot 1106$ & اقتصد & |قتصد \\
\hline بقصدون & قصد ، اقتصد ، & $3 \cdot 3 \cdot 1$ & 1602 ، 1906 ، $\underline{\mathbf{1 2 0 6}}$ & قصد & قصد \\
\hline استخدم & اقتصد ، خدد ، خدم & $3 \cdot 2 \cdot 3$ & $\underline{\mathbf{1 2 0 6}}$ ، 1404 ، 1906 & 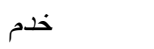 & 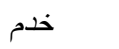 \\
\hline سنستدرجهم & أقتصد ، خدم ، هزم & $1 \cdot 1 \cdot 3 \cdot 1$ & $\begin{array}{r}\text { ‘2706 } \cdot 3102 \cdot 3802 \\
3102\end{array}$ & ل درج & درج \\
\hline متذبذب & كتب ، ذبذب & $1 \cdot 4$ & $\underline{\mathbf{5 0 8}} \cdot 1002$ & نبذب & نبذب \\
\hline متلألهئ & عمل ، كمل ، تأتأ ، & $1 \cdot 1 \cdot 1 \cdot 3$ & $\begin{array}{r}\cdot 1402 \cdot 1 \overline{302} \cdot 1302 \\
1006\end{array}$ & $y y$ & $y y$ \\
\hline 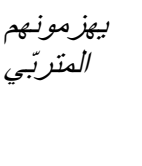 & 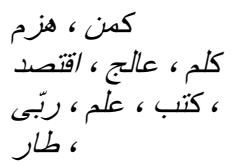 & $\begin{array}{l}1 \cdot 3 \\
1 \cdot 1 \cdot 1 \cdot 1 \cdot 1 \\
66 \cdot 1\end{array}$ & $\begin{array}{r}2006 \text { ، } \mathbf{2 4 0 2} \\
\cdot 3602 ، 3202 \cdot 2902 \\
\cdot \underline{\mathbf{2 2 1 2}} \text { ، } 2902 \text { ، } 2902 \\
2902\end{array}$ & هزبّى & رنبّى \\
\hline المربّبن & 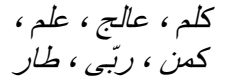 & $\begin{array}{l}1 \cdot 1 \cdot 1 \cdot 1 \cdot 3 \\
6\end{array}$ & $\begin{array}{r}\text { ، } 2902 \text { ، } 3202 \text { ، } 2902 \\
2902 \text { ، } 29002\end{array}$ & ريّبى & رِّبى \\
\hline طائر/ت & اقتصد ، طار & $3 \cdot 1$ & $\underline{\underline{1006}} \cdot 2102$ & طار & طار \\
\hline
\end{tabular}

Table 6. Obtained results when extracting the words roots.

\begin{tabular}{lllllll}
\hline Corpus & Nb.Roots & Nb.Words & Cor. Results & Wr.Results & Suc.Rate & Err.Rate \\
\hline Small & 25 & 50 & 49 & 1 & 98,00 & 2,00 \\
Middle & 135 & 270 & 253 & 17 & 94,07 & 5,93 \\
Large & 450 & 1500 & 1358 & 142 & 90,53 & 9,47 \\
\hline
\end{tabular}

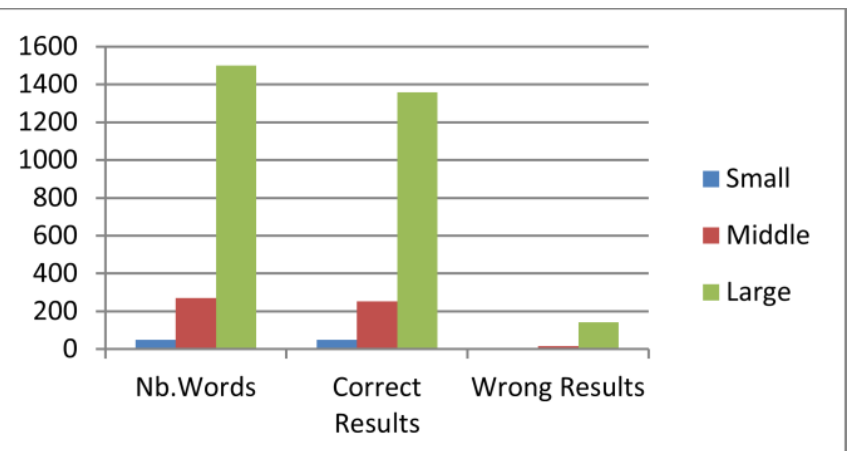

Fig. 1. Correct and wrong results in number of words. 


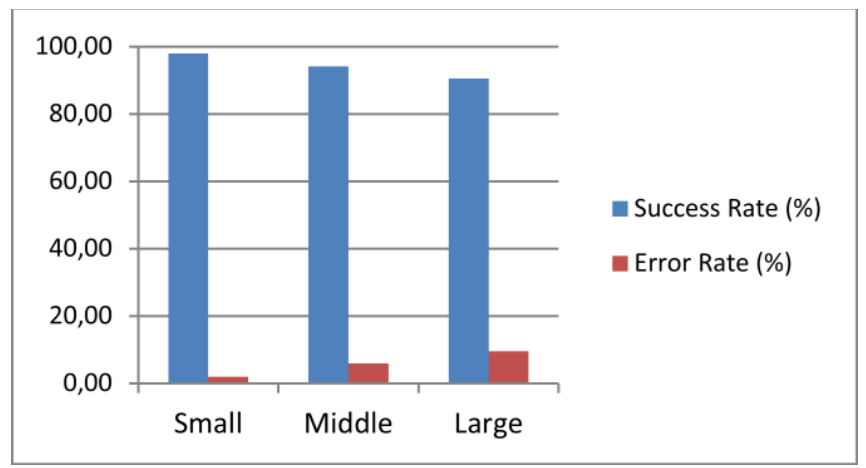

Fig. 2. Calculation of success rate and error rate.

\section{Comparison with other algorithms}

To show the effectiveness of our proposed algorithm, we concluded our work by establishing a comparison against other known algorithms. For this purpose, we took a sample words list and tried to extract the root of each word using three very known algorithms which are: khodja stemmer, Nidal et al stemmer, and our proposed stemmer, the obtained results are shown in table 7.

In the other hand, we illustrated the obtained results when applying the three above algorithms on the three corpus used in the experimentation, namely: the small corpus, the middle corpus, and the large corpus, and then we summarized the obtained accuracy for each algorithm in table 8 .

Table 7. Extraction of some words roots using the three algorithms.

\begin{tabular}{|c|c|c|c|c|}
\hline \multirow[t]{2}{*}{ Word } & \multicolumn{4}{|c|}{ Extracted root } \\
\hline & Khodja algorithm & $\begin{array}{l}\text { Nidal et al } \\
\text { algorithm }\end{array}$ & $\begin{array}{l}\text { Our proposed } \\
\text { algorithm }\end{array}$ & Correct root \\
\hline بتئُمون & 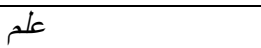 & 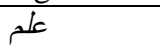 & 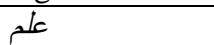 & علم \\
\hline كاتب & كتب & كتب & كتب & كتب \\
\hline 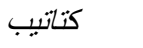 & Not stemmed & كتب & كتب & كتب \\
\hline اقتصاد & قصد & اقتصد & |قتصد & اقتصد \\
\hline سنستدرجهم & Not stemmed & 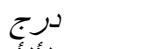 & ن درج & د درج \\
\hline 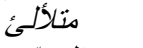 & Not stemmed & $y$ & $y y$ & 88 \\
\hline المربّبي & 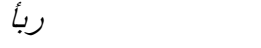 & رِبّى & رِّبى & رِبّى \\
\hline المربّون & 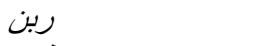 & رِبّى & ريّبى & ريّبى \\
\hline طائرات & طور & 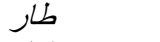 & طار & طار \\
\hline 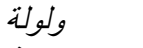 & 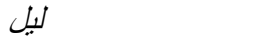 & 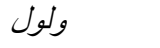 & 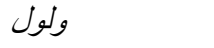 & 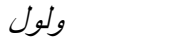 \\
\hline وقبعة & قوع & وقع & وقع & وقع \\
\hline يزنونهم & & نسب & وزن & وزن \\
\hline زلازل & Not stemmed & ت ت تنازل & زلزل & زلزل \\
\hline حو/سبب & Not stemmed & نسي & حسب & حسب \\
\hline ن نوازل & ل & تنازل & نزل & نزل \\
\hline
\end{tabular}


Table 8. Illustration of obtained accuracy for the three algorithms

\begin{tabular}{|c|c|c|c|c|c|c|c|c|}
\hline \multirow[t]{2}{*}{ Corpus } & \multicolumn{3}{|c|}{ Size } & \multicolumn{5}{|c|}{ The obtained accuracy (suc_rate, err_rate)\% } \\
\hline & Nb.roots & Nb.words & $\begin{array}{l}\text { Khodj } \\
\text { algori }\end{array}$ & & $\begin{array}{l}\text { Nidal } \\
\text { algori }\end{array}$ & & $\begin{array}{l}\text { Our } \mathrm{p} \\
\text { algori }\end{array}$ & $\begin{array}{l}\text { posed } \\
\mathrm{m}\end{array}$ \\
\hline Small & 25 & 50 & 68,00 & 32,00 & 92,00 & 8,00 & 98,00 & 2,00 \\
\hline Middle & 135 & 270 & 83,70 & 16,30 & 63,33 & 36,66 & 94,07 & 5,93 \\
\hline Large & 450 & 1500 & 73,26 & 26,74 & 57,79 & 42,21 & 90,53 & 9,47 \\
\hline
\end{tabular}

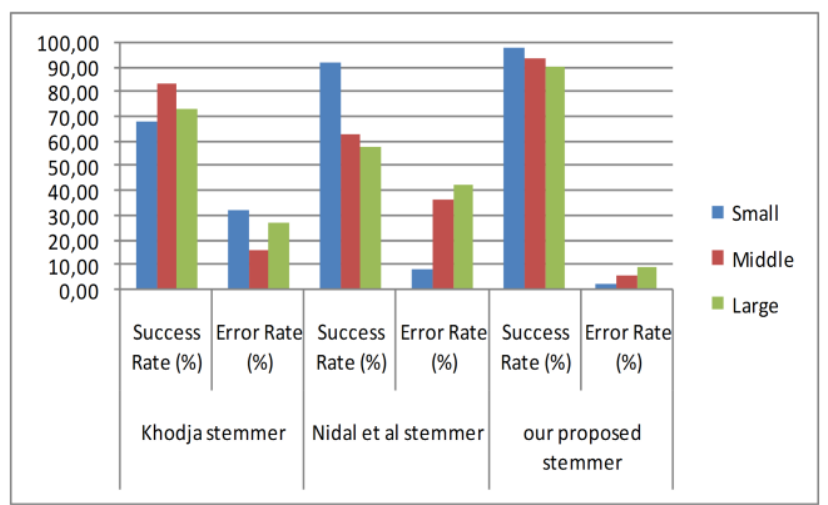

Fig. 3. Comparison between three algorithms

\section{Discussion}

From table 7, we see that khodja stemmer algorithm fails sometimes in getting the correct root of the given word and for many words it produced one of two results: (1) not stemmed (i.e., سنستنرجهم , منتلألئ , حواسيب) completely a new word and sometimes a

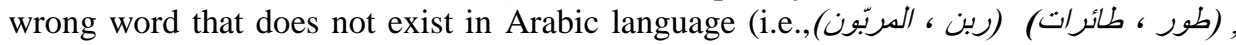
(قوع ، وقيعة) ( The same thing can be said for Nidal et al algorithm although it's gives best results than khodja algorithm, but it fails for many words like : (سجد، ناسج), (سني، حواسيب) (سنن ، يزنونهم), For the same cases, our algorithm gives always the correct root and the failure in our algorithm is very limited.

From Table 8 and figure 3, we can deduce that our proposed algorithm gives the best results for the three used corpus with a very high accuracy. We note here the value 98 $\%$ for the small corpus, $94,07 \%$ for the middle corpus, and $90,53 \%$ for the large corpus

\section{Conclusion and Perspectives}

In this paper we have studied how we can reduce the size of terms in Arabic text categorization by replacing many words by their common root. In this purpose, we exposed the most known algorithms and techniques in the field, Including morphological algorithms mainly based on the use of morphological rules and grammatical patterns of Arabic, and statistical algorithms which are the newest in the 
field, and require only simple calculations of distances. We also proposed a new statistical algorithm based on bigrams technique. This algorithm is fast and easy to implement on machine, does not require the removal of affixes nor the use of any morphological rules and grammatical patterns, capable to find all types of roots, i.e., trilateral, quadrilateral, quinquelateral, and hexalateral roots. There is no difference between strong roots and vocalic roots in our new algorithm. We also established a comparison between our proposed algorithm and two other algorithms which are very known in the field, namely: Khodja algorithm, Nidal et al algorithm. The first one fails sometimes in getting the correct root of the given word and for many words it produced one of two results: (1) not stemmed word (2) completely a new word and sometimes a wrong word that does not exist in Arabic. The same thing can be said for second one, although it gives best results than the first, but it fails for many words. For the same cases, our new algorithm gives always the correct root, the failure is very limited, and the obtained success ratio of root extraction is very promising.

In our future work, we plan to apply our new algorithm on corpus of Arabic words with big sizes, to improve the obtained success rate, and to apply it in extracting the root of words in other languages such as English and French.

\section{References}

1. Fatma, A.H., Keith, E.: Rule-based Approach for Arabic Root Extraction: New Rules to Directly Extract Roots of Arabic Words. Journal of Computing and Information Technology CIT journal, Zaghreb, 57-68. (2014)

2. Ghazzawi, S.: The Arabic Language in the Class Room. 2nd EDN, Georgetown University, Washington DC. (1992)

3. ETHNOLOGUE, http://www.ethnologue.com/statistics/size. accessed 16 January 2014.

4. Al-Kamar, R.: Computer and arabic language computerizing. Dar Al Kotob Al-Ilmiya, Cairo, Egypt. (2006)

5. Ghwanmeh, S., G. Kanaan, R. Al-Shalabi and S. Rabab'ah: Enhanced algorithm for extracting the root of Arabic words. In: Proceeding of the 6th International Conference on Computer Graphics, Imaging and Visualization, Aug. 11-14, IEEE Xplore Press, Tianjin, Chain, pp: 388-391. (2009)

6. Yousef, N., I. Al-Bidewi and M. Fayoumi.: Evaluation of different query expansion techniques and using different similarity measures in Arabic documents. Eur. J. Sci. Res., 43, 156-166. (2010).

7. Wightwick, J. and M. Gaafar. : Arabic Verbs and Essentials of Grammar, 2E (Verbs and Essentials of Grammar Series). 2nd EDN., McGraw-Hill Companies, Inc., ISBN-10: 0071498052, pp: 160 (2007).

8. Al-omari, A., Abuata, B., Al-kabi, M.: Building and Benchmarking New Heavy/Light Arabic Stemmer. In: The 4th International conference on Information and Communication systems (ICICS'13), (2013).

9 Shereen, K., Garside, R.: Stemming Arabic text. Technical report, Computing Department, Lancaster niversity, 1999., [online] available: http://www.comp.lancs.ac.uk/computing/users/khoja/stemmer.ps, last visited 1999.

10. Momani, M., Faraj, J.: A novel algorithm to extract tri-literal Arabic roots. In: Proceedings of the IEEE/ACS International Conference on Computer Systems and Applications. May 1316, IEEE Xplore Press, Amman, pp: 309-315. (2007).

11. Al shalabi, R.: Pattern-based stemmer for finding Arabic roots. Information Technology Journal, Vol.4, No.1, 38-43. , (2005). 
12. Hajjar, A.E.S.A., M. Hajjar., Zreik, K.: A system for evaluation of Arabic root extraction methods. In: Proceeding of 5th International Conference on Internet and Web Applications and Services (ICIW), May 9-15, IEEE Xplore Press, Barcelona, pp: 506-512. (2010).

13. Al-Nashashibi, M.Y., D. Neagu., Yaghi,A.A.: An improved root extraction technique for Arabic words. In: Proceeding of 2nd International Conference on Computer Technology and Development (ICCTD), Nov. 2-4, IEEE Xplore Press, Cairo, pp: 264-269. (2010).

14. Al-shalabi, R., Kanaan, G., Al-Serhan, H.: New Approach for Extracting Arabic Roots. In: Proceedings of the International ArabConference on Information Technology (ACIT'20003), Alexandria, Egypt, pp. 42-59. (2003).

15. Rehab, D.: Arabic Text Categorization. The International Arab Journal of Information Technology, vol. 4, No. 2, 125-131. (2007).

16. Al-Nashashibi, M. Y., Neagu, D., Ali. A. Y.: Stemming Techniques for Arabic Words: A Comparative Study. In: 2nd International Conference on Computer Technology and development (1CCTD 2010), 270-276. (2010).

17. Kanaan, G., Al-Shalabi, R., and Al-Kabi, M.:New Approach for Extracting Quadrilateral Arabic Roots. Abhath Al-Yarmouk, Basic Science and Engineering. Vol. 14, No.1, 51-66. (2005).

18. Ghwanmeh S., Al-Shalabi R., Kanaan G., Khanfar K. and Rabab'ah S.: An Algorithm for extracting the Root of Arabic Words. In: Proceedings of the 5th International Business Information Management Conference (IBIMA). Cairo, Egypt. (2005).

19. Mohamad, A., Al-Shalabi, R., Kanaan, G., and Al-Nobani, A: Building an Effective RuleBased Light Stemmer for Arabic Language to Improve Search Effectiveness. The International Arab Journal of Information Technology, Vol. 9, No. 4, July 2012, Received February 22, 2010; accepted May 20, 2010

20. Al-Shalabi, R., Kanaan, G., Ghwanmeh, S.: Stemmer Algorithm for Arabic Words Based on Excessive Letter Locations. IEEE Conference, (2008).

21. Shereen, K.: Stemming Arabic Text. [online]. Available: http://zeus.cs.pacificu.edu/shereen/research.htm

22. Larkey L., and M. E. Connell. : Arabic information retrieval at UMass in TREC-10.In: Proceedings of TREC 2001, Gaithersburg: NIST (2001)

23. Larkey, S., Ballesteros, L., Margaret, Connell, E.: Improving Stemming for Arabic Information Retrieval: Light Stemming and Occurrence Analysis. In: Proc. of the 25th ACM International Conference on Research and Development in Information Retrieval (SIGIR'02), Tampere, Finland, pp.275-282, (2002).

24. Larkey, S., Ballesteros, L., Margaret, Connell, E.: Light Stemming for Arabic Information Retrieval, Arabic Computational Morphology Text, Speech and Language Technology Vol. 38, 221-243. (2007)

25. Sawalha, M., Atwell, E.: Comparative Evaluation of Arabic Language Morphological Analyzers and Stemmers. In: Proceedings of COLING-ACL. (2008)

26. Hawas, F.A.: Exploit relations between the word letters and their placement in the word for Arabic root extraction. Comput. Sci, Vol 14, 27-431.

27. Hmeidi, I.I., Al-Shalabi, R., Al-Taani, A.T., Najadat, H., and Al-Hazaimeh, S.A.: A novel approach to the extraction of roots from Arabic words using bigrams. J. Am. Soc. Inform. Sci. Technol., Vol. 61, 583-591. (2010)

28. Boudlal, A., Belahbib, R., Belahbib, A., Mazroui, A.: A markovian approach for Arabic root extraction. Int. Arab J. Inform. Technol, Vol. 8, 91-98.( 2011)

29. Yousef, N., Aymen, A.E., Ashraf, O., Hayel, K.: An Improved Arabic Word's Roots Extraction Method Using N-gram Technique, Journal of Computer science JSC. Vol. 10, No. 4 (2014), Published Online (http://www.thescipub.com/jcs.toc).

30. Frakes, W.B.: Stemming Algorithms. In: Information Retrieval: Data Structures and Algorithms, Frakes, W.B. and R. Baeza-Yates (Eds.), Prentice-Hall India, ISBN-10: 8131716929, pp: 131-160. (1992) 